\title{
Targeting of cigarette advertising in US magazines, 1959-86
}

\author{
Kenneth E Warner, Linda M Goldenhar
}

\begin{abstract}
Objective To examine whether and to what extent targeting of cigarette advertising has occurred in magazines in the United States from 1959 to 1986.

Design Analysis of data on advertising revenues and readership demographics for 92 magazines categorized by type of magazine (women's, sports, news, high brow) and by the occupational class of the readership (crafts and trade and professional).

Main outcome measures Relative share of cigarette advertising revenue for each category (the category's percentage of cigarette advertising revenues in the sample of 92 magazines divided by its percentage of total advertising revenues). Results Over the 28 years studied the relative share of cigarette advertising increased significantly in women's magazines ( $0 \cdot 14$ to $1 \cdot 11)$, sports magazines $(1 \cdot 23$ to 1.76 ), and magazines with predominantly blue collar readerships $(1.04$ to 1.78).
\end{abstract}

The relative share of high brow magazines (those focusing on political and intellectual commentary and scientific matters) fell (1.36 to 0.63). By 1986 blue collar and sports magazines had shares of cigarette advertising revenue that were three quarters larger than their share of advertising revenue in general. Over the entire period relative shares of cigarette advertising revenue grew more rapidly for women's magazines than for any of the other categories studied, in part reflecting the fact that women's magazines had the lowest relative share of cigarette advertising at the beginning of the period.

Conclusion In general, our findings are consistent with commonly held beliefs about the nature of targeting in cigarette advertising.

School of Public Health and Institute of Gerontology, University of

Michigan, Ann Arbor, Michigan 48109-2029,

USA

KE Warner

L M Goldenhar

Correspondence to: Dr Warner.

\section{Introduction}

In recent years the health community in the United States has exhibited increasing concern about the tobacco industry's targeting of women, children, people from minority groups, and blue collar workers in advertising and promotional campaigns. ${ }^{1-5}$ These groups are perceived to be more vulnerable to the sales efforts of the cigarette manufacturers than is the traditional mainstay of the industry, the middle class white male, the group that has stopped smoking in larger numbers than any other. ${ }^{6}$ In addition to concerns about exploitation, in the case of African-Americans, such targeting raises the prospect of worsening health conditions for the segment of the American population already experiencing the nation's poorest health statistics, in part due to its higher prevalence of smoking.?

Recent analysis shows that billboard advertisements for cigarettes are found disproportionately in inner cities whose population is predominantly black (D P Hackbarth et al, 119th annual meeting of the American Public Health Association, Atlanta, Georgia, November 1991). Advertising analysts have described cigarette marketers' shifting their advertisements from magazines with white collar readerships to those with blue collar readerships. ${ }^{8}$ Targeting by the industry of women through advertising dates from the late 1960 s with the emergence of Virginia Slims cigarettes. ${ }^{1}$ Targeting of children is an old story too, one that has received increasing attention of late because of the remarkable, and apparently successful, series of Camel cartoon advertisements. ${ }^{2-4}$ Increasing use of sports promotions is seen as a means of reaching both children and the blue collar population. ${ }^{9}$

Using a database of advertising revenues and readership demographics for 92 magazines over a 28 year period, we examined whether and to what extent some of these alleged shifts in cigarette advertising had taken place in US magazines. Because of an inadequate number of magazines with minority group readerships in the database we were unable to evaluate purported shifts in advertising from magazines with a white readership to those with a minority group readership. Similarly, we had no data on youthful readerships, but we were able to analyse trends by occupational class and magazine type.

\section{Methods}

DATA AND CLASSIFICATION OF MAGAZINES

We collected data on readership demographics and advertising revenues (cigarette and all other) for 92 magazines for the period 1959-86. Selection of the magazines was dictated by the availability of these and other data, as described in two previous publications. ${ }^{1011}$ Data on readership demographics came from Simmons Market Research and data on advertising from Leading National Advertisers/ Publishers Information Bureau. 
Table 1 Distribution of magazines by magazine type and by occupational class. * Number of years with data on advertising revenue for each magazine is given in parentheses

\begin{tabular}{|c|c|c|}
\hline \multicolumn{2}{|l|}{ Magazine type } & $\begin{array}{l}\text { Occupational class } \\
\text { Professional: } \\
\text { Atlantic (28) } \\
\text { Business Week (28) } \\
\text { Cuisine (4) } \\
\text { Discover (7) } \\
\text { Dun's Business Monthly (28) } \\
\text { Forbes (28) } \\
\text { Fortune (28) } \\
\text { Harpers (28) } \\
\text { National Geographical (28) } \\
\text { New York (18) } \\
\text { New York Times Magazine (28) } \\
\text { New Yorker (28) } \\
\text { Psychology Today (16) } \\
\text { Saturday Review (24) } \\
\text { Scientific American (20) } \\
\text { Smithsonian (14) } \\
\text { Sunset (28) } \\
\text { US News And World Report (28) }\end{array}$ \\
\hline $\begin{array}{l}\text { Sports: } \\
\text { Car and Driver (15) } \\
\text { Golf (23) } \\
\text { Hot Rod (14) } \\
\text { Motor Trend (16) } \\
\text { Outdoor Life (28) } \\
\text { Road and Track (14) } \\
\text { Skin Diver (16) } \\
\text { Sport (28) } \\
\text { Sporting News (6) } \\
\text { Sports Afield (28) } \\
\text { Sports Illustrated (28) } \\
\text { World Tennis (14) } \\
\text { News: } \\
\text { Newsweek (28) } \\
\text { Time (28) } \\
\text { US News and World Report (28) } \\
\text { High brow: } \\
\text { Atlantic (28) } \\
\text { Discover (7) } \\
\text { Harpers (28) } \\
\text { National Geographic (28) } \\
\text { New Republic (2) } \\
\text { New York (18) } \\
\text { New York Times Magazine (28) } \\
\text { New Yorker (28) } \\
\text { Omni (9) } \\
\text { Popular Science (28) } \\
\text { Psychology Today (16) } \\
\text { Saturday Evening Post (14) } \\
\text { Saturday Review (24) } \\
\text { Science Digest (6) } \\
\text { Scientific American (20) } \\
\text { Smithsonian (14) } \\
\text { World Press Review (8) } \\
\text { Women's: } \\
\text { Better Homes and Gardens (28) } \\
\text { Cosmopolitan (28) } \\
\text { Family Health (9) } \\
\text { Glamour (28) } \\
\text { Good Housekeeping (26) } \\
\text { Harper's Bazaar (28) } \\
\text { House \& Garden (28) } \\
\text { House Beautiful (28) } \\
\text { Ladies Home Journal (28) } \\
\text { Madmoiselle (28) } \\
\text { McCalls (28) } \\
\text { MS (12) } \\
\text { Parent's Magazine (28) } \\
\text { Redbook (28) } \\
\text { Seventeen (28) } \\
\text { Weight Watchers (4) } \\
\text { Woman's Day (28) } \\
\text { Working Woman (8) } \\
\text { Wol }\end{array}$ & $\begin{array}{l}\text { Other } \star \\
\text { Architectural Digest (10) } \\
\text { Black Enterprise (16) } \\
\text { Boy's Life (28) } \\
\text { Business Week (28) } \\
\text { California (New West) (11) } \\
\text { Changing Times (7) } \\
\text { Consumer Digest (4) } \\
\text { Cuisine (4) } \\
\text { Dun's Business Monthly (28) } \\
\text { Ebony (28) } \\
\text { Esquire (28) } \\
\text { Essence (12) } \\
\text { Family Handyman (6) } \\
\text { Forbes (28) } \\
\text { Fortune (28) } \\
\text { Gourmet (27) } \\
\text { Harvard Business Review (28) } \\
\text { Inc (6) } \\
\text { Industry Week (10) } \\
\text { Life (23) } \\
\text { Metropolitan Home (12) } \\
\text { Modern Bride (28) } \\
\text { Modern Maturity (6) } \\
\text { Money (16) } \\
\text { Nation's Business (28) } \\
\text { Natural History (14) } \\
\text { Penthouse (16) } \\
\text { People Weekly (11) } \\
\text { Playboy (28) } \\
\text { Popular Mechanics (28) } \\
\text { Prevention (4) } \\
\text { Reader's Digest (28) } \\
\text { Rodale's Organic Gardening (6) } \\
\text { Rolling Stone (10) } \\
\text { Sunset (28) } \\
\text { Teen (8) } \\
\text { Texas Monthly (8) } \\
\text { Town \& Country (22) } \\
\text { Travel-Holiday (27) } \\
\text { TV Guide (28) } \\
\text { Vogue (28) } \\
\text { 50 Plus (Retirement Living) (7) }\end{array}$ & $\begin{array}{l}\text { Professional: } \\
\text { Atlantic (28) } \\
\text { Business Week (28) } \\
\text { Cuisine (4) } \\
\text { Discover (7) } \\
\text { Dun's Business Monthly (28) } \\
\text { Forbes (28) } \\
\text { Fortune (28) } \\
\text { Harpers (28) } \\
\text { National Geographical (28) } \\
\text { New York (18) } \\
\text { New York Times Magazine (28) } \\
\text { New Yorker (28) } \\
\text { Psychology Today (16) } \\
\text { Saturday Review (24) } \\
\text { Scientific American (20) } \\
\text { Smithsonian (14) } \\
\text { Sunset (28) } \\
\text { US News And World Report (28) } \\
\text { Crafts and trade: } \\
\text { Car and Driver (15) } \\
\text { Esquire (28) } \\
\text { Hot Rod (14) } \\
\text { Motor Trend (16) } \\
\text { Penthouse (16) } \\
\text { Playboy (28) } \\
\text { Popular Mechanics (28) } \\
\text { Popular Science (28) } \\
\text { Road and Track (14) } \\
\text { Sport (28) } \\
\text { Sporting News (6) } \\
\text { Sports Afield (28) } \\
\text { Sports Illustrated (28) }\end{array}$ \\
\hline
\end{tabular}

$\star$ Professional and crafts and trade categories are mutually exclusive from each other but not from the five magazine types.

We used the Simmons data to classify all magazines into three occupational categories: professional, crafts and trade, and other. A magazine was categorised as having a professional readership, our proxy for white collar, if it fell into the top quartile of all magazines in terms of the readership classified as having professional occupations. (We sampled readership distributions for five representative years spanning the study period. A magazine was categorised as having a professional readership if it was in the top quartile during one or more of those five years.) Similarly, a magazine was considered to be crafts and trade, our proxy for blue collar category, if its readership fell into the top quartile of magazines ranked by readers in the crafts and trade occupational classes.

We also classified the 92 magazines into five categories of magazine type: women's, sports, news, high brow (those focusing on political and intellectual commentary and scientific matters), and other. We used the Simmons demographic data to classify a magazine as a women's magazine when at least three quarters of the readership was female. For the re- maining categories we modified the classification scheme found in Ulrich's International Dictionary, as explained in a recent article. ${ }^{11}$ Although these five categories of magazine type are mutually exclusive, they overlap with the separately defined occupational categories (table 1).

\section{ANALYSIS}

For each magazine type and each occupational category we calculated an index value of cigarette advertising concentration for each year from 1959 to 1986 . The index, the unit of analysis of the study, is the ratio of two percentages: (a) the category's share of cigarette advertising revenues for the year and $(b)$ the category's share of total advertising revenues (for all products) for the year. The share of cigarette advertising was calculated by summing all cigarette advertising revenues in magazines in the individual category-for example, sports - during a given year and then dividing by the total of all cigarette advertising revenues in the entire sample of 92 magazines 
that year. Similarly, the denominator of our index was calculated by summing total advertising revenue in magazines in the specific category and dividing by total advertising revenues in all sample magazines, again for the given year.

From this calculation the index value indicates how a category's share of cigarette advertising revenue compares with its share of all advertising revenue; we refer to it, therefore, as the relative share of cigarette advertising revenue. Were we to examine only the numerator - the category's share of cigarette advertisements - we might confuse the category's dependence on cigarette advertising revenues with its overall "size" or "importance" among magazines.

An example may help to clarify this point. From 1983 to 1986 the 14 women's magazines in our sample had almost $30 \%$ of the revenue from cigarette advertising in all of the magazines in the sample, $\$ 298$ million out of a total of $\$ 1.06$ billion in cigarette advertising during the four year period. This might suggest an enormous dependence on cigarette advertising as a source of advertising revenue. Alternatively, it might simply represent women's magazines having a large percentage of all advertisements in our sample of magazines. In fact, women's magazines' share of cigarette advertising revenues $(28 \%)$ was only slightly larger than their share of all advertising revenues $(25 \%$, or $\$ 3.8$ billion out of $\$ 14.9$ billion in total advertising revenue for all magazines in the sample). This is reflected in an index value just slightly greater than 1.0 (see table 2) when women's magazines' share of cigarette advertising was adjusted by their share of all advertising. Their actual dependence on cigarette advertising during the four year period is indicated by dividing their cigarette advertising revenues by their total advertising revenues, yielding $8 \%$.

To determine whether there was a significant linear time trend for each magazine category we ran an ordinary least squares regression with the annual index value as the dependent variable and the year as the independent variable (coded as 1 for 1959, 2 for 1960, etc). Because magazines go in and out of print the number of magazines used for each yearly observation varied. To ensure that the number of magazines used for each observation did not skew the results we also ran a weighted least squares regression for each category, with the weight equalling the number of magazines in each year. The results for the two sets of regressions were virtually identical. We report results from the weighted regressions.

\section{Results}

Table 2 presents the index values over the 28 year period for the six categories of interest (four magazine types and two occupational classes; the magazine category other was omitted). Although annual values were used in the regressions, table 2 shows averages for four year periods to make the time trends easier to visualise.

Table 3 presents coefficients for the year variable estimated in the weighted least squares regressions. The coefficient indicates the amount by which the relative share of cigarette advertising revenue (the index value) increases with the passage of each year (or decreases, as in the case of the negative coefficient estimate). As such, a larger positive coefficient indicates more rapid growth in the relative share of cigarette advertising than does a smaller coefficient.

The results indicate significant $(p<0.001)$ increases over time in the relative share of cigarette advertising received by women's magazines, sports magazines, and magazines with predominantly blue collar readerships; the relative share of high brow magazines fell with time. (Small but significant increases in the index values for news magazines and magazines with professional readerships are considered below separately from discussion of these expected trends.) Growth in the relative share of cigarette advertisements was most rapid in the case of women's magazines, with the index value increasing an estimated 0.047 points per year; the next most rapid rate of growth was in the crafts and trade (blue collar) category $(0.035)$, followed closely by sports magazines $(0.032)$ (table 3$)$.

During the final four year period studied, 1983-6, crafts and trade and sports magazines had the most substantial excess share of cigarette advertising revenues, as reflected by index values of 1.78 and 1.76 (table 2 ). These values mean that these two categories' shares of cigarette advertising revenues exceeded their shares of all advertising revenues by more than three quarters. In contrast, women's magazines had a share of cigarette advertising revenues just slightly $(11 \%)$ higher than their share of advertising revenues in general (as reflected in an index value of $1 \cdot 11$ ).

Table 2 Relative shares of cigarette advertising revenue (index values ${ }^{\star}$ ) by magazine category and year

\begin{tabular}{|c|c|c|c|c|c|c|}
\hline \multirow[b]{3}{*}{ Year } & \multicolumn{6}{|c|}{ Magazine category } \\
\hline & \multicolumn{4}{|c|}{ Magazine type } & \multicolumn{2}{|l|}{ Occupational class } \\
\hline & Women's & Sports & News & High brow & Crafts and trade & Professional \\
\hline $\begin{array}{l}1959-62 \\
1963-6 \\
1967-70 \\
1971-4 \\
1975-8 \\
1979-82 \\
1983-6\end{array}$ & $\begin{array}{l}0 \cdot 14 \\
0 \cdot 17 \\
0 \cdot 24 \\
0 \cdot 58 \\
0 \cdot 82 \\
1 \cdot 08 \\
1 \cdot 11\end{array}$ & $\begin{array}{l}1.23 \\
1.03 \\
1.21 \\
1.57 \\
1.56 \\
1.63 \\
1.76\end{array}$ & $\begin{array}{l}1.05 \\
1.23 \\
1.25 \\
1.52 \\
1.84 \\
1.69 \\
1.44\end{array}$ & $\begin{array}{l}1.36 \\
1.49 \\
0 \cdot 73 \\
0 \cdot 38 \\
0.53 \\
0.50 \\
0 \cdot 63\end{array}$ & $\begin{array}{l}1.04 \\
1.04 \\
1.29 \\
1.59 \\
1.60 \\
1.60 \\
1.78\end{array}$ & $\begin{array}{l}0.25 \\
0.17 \\
0.47 \\
0.38 \\
0.44 \\
0.37 \\
0.32\end{array}$ \\
\hline
\end{tabular}

$\star$ See text for calculation. 
Table 3 Estimated coefficients for year variable (weighted least squares regressions)

\begin{tabular}{lr}
\hline Magazine category & Coefficient $^{\star}$ \\
\hline Magazine type: & \\
Women's & 0.047 \\
Sports & 0.032 \\
News & 0.024 \\
High brow & -0.035 \\
Occupational class: & \\
Crafts and trade & 0.035 \\
Professional & 0.007 \\
\hline
\end{tabular}

* All significant at $\mathrm{p}<0.001$.

The two magazine categories likely to have the highest education readerships, and hence readers with the lowest prevalence of smoking, ${ }^{6}$ had the lowest index values: in 1983-6 high brow magazines' share of cigarette advertisements was less than two thirds of their share of all advertising (index value 0.63 ) and magazines having a professional readership received a share of cigarette advertising revenues equalling only a third of their share of all advertising (index value 0.32 ). In contrast, news magazines, also having a well educated readership, received cigarette advertising disproportionately greater than their share of all advertising throughout the 28 year period (table 2).

\section{Discussion}

Much of the public concern about targeting has focused on cigarette manufacturers' targeting of women in their advertising campaigns. ${ }^{1}$ This may be particularly important in the case of magazines, since it has been alleged that as a result of dependence on cigarette advertising revenues women's magazines have been especially subject to self censorship about the health effects of smoking. ${ }^{12-15}$ Our recent research strongly supports this allegation. ${ }^{11}$

Viewed in this context, our findings on women's magazines are particularly interesting. Among all the categories examined over the 28 years investigated, women's magazines experienced the most substantial increase in their relative share of cigarette advertising. Nevertheless, their relative share at the end of the period (in the mid-1980s) was close to average for all magazines - that is, their index value (averaging $1 \cdot 1$ for the last eight years) was close to the value indicating a proportionate share $(1 \cdot 0)$. The dramatic growth in their relative share of cigarette advertisements resulted more from the miniscule share they received during the 1960 s (index value ranging from 0.14 to 0.24 ) than from a disproportionately large share in the mid-1980s (table 2). As a consequence our data are not consistent with the common belief that cigarette advertisers disproportionately targeted readers of women's magazines through the mid-1980s, although the relative growth rate of cigarette advertising in women's magazines exhibits a clear pattern of increasing interest in the female smoking marketplace. Furthermore, the 1986 end point of this study means that we were unable to assess whether greater targeting is occurring today. Nevertheless, our other research suggests that cigarette advertisers have received a disproportionate "bang for the buck" in women's magazines in discouraging discussion of the hazards of smoking. ${ }^{11}$

Our findings concerning the occupational categories are consistent with the conventional wisdom. Next to women's magazines, the crafts and trade magazines - our measure of blue collar readership - showed the strongest upward trend in the share of cigarette advertising over the entire 28 year period. Unlike women's magazines, however, the blue collar magazines started the period with an average concentration of cigarette advertisements. By the end of the period their relative share of cigarette advertising was three quarters greater than that of the average magazine. The fact that the professional category did not experience a substantial decline in its (already low) relative share of cigarette advertising simply indicates that the residual (other) category did experience such a decline. This residual category includes magazines with neither a large professional readership nor a large blue collar readership. By default, the other category includes middle class readers including workers classified as managerial and clerical and also those not employed.

Also consistent with expectation, sports magazines showed a strong increasing trend in relative share of cigarette advertising over the period and a sizable relative share independent of trend. There is considerable overlap in the sports and crafts and trade categories (two thirds).

The strong decline in the share of cigarette advertising in the high brow magazines is as anticipated but is noteworthy none the less for the fact that these magazines captured a disproportionately large fraction of cigarette advertisements in the early years until the mid1960 s (index values of 1.36 and 1.49 for 1959-62 and 1963-6, respectively). The 1950s and early 1960s were the years of national "discovery" of the dangers of smoking, highlighted by the publication of the first Surgeon General's report on smoking and health in $1964 .^{16}$ In ensuing years this category of magazines experienced a plummeting relative share of cigarette advertising, its index value halving from the early to the late 1960s and halving again in the early 1970s (rebounding slightly thereafter) (table 2).

Given their relatively highly educated (and hence low smoking) readership, the fact that news magazines captured a disproportionately large amount of cigarette advertising throughout the 28 year period is somewhat perplexing. All of the other categories have index values consistent with the smoking prevalence of their dominant readerships (low index values for professional and high brow magazines, with readerships having a low smoking prevalence, and high index values for crafts and trade and sports magazines, with readerships having a high smoking prevalence). A possible explanation may lie in the role of news magazines. As purveyors of news and commentary on the nation's pressing issues the news magazines may constitute an important target for cigarette advertising intended to 
mute discussion of the hazards of smoking. Such magazines do provide more discussion of these dangers than do other magazines (including other magazines that devote attention to health issues), but they are not immune from the pressures to restrict such coverage. ${ }^{1117}$

An unexpected finding from this analysis was the significant time trends in news magazines and magazines with a more professional readership (table 3). On close examination, however, this is readily explained. The trend in news magazines is clearly upward during the first 20 years covered, accounting for the significant positive time trend in our data, but it is then downward during the 1980s. The magnitude of the trend for the professional readership magazines is the smallest of all six categories by far (with the index value increasing an estimated 0.007 per year), reflecting a small increase in the index value from the early years to the middle of the period, and then a subsequent decrease. The decrease is smaller than the initial increase, accounting for the overall slight positive trend. In all periods the magazines with a professional readership had a disproportionately small share of cigarette advertising compared with all other advertising (table 2).

The findings pertaining to the news and professional categories show three critical factors in interpreting these data. Firstly, as just noted, the magnitude of the index during the entire period is at least as important as the time trend. For example, though magazines with professional readerships did not experience a decrease in their relative share of cigarette advertising, as we had expected, the small index value throughout the period means that the cigarette industry never targeted a professional audience during the three decades studied.

Secondly, by limiting the analysis to investigation of a simple linear time trend we have not examined statistically the possibility of more complex non-linear trends. The index values for both magazines with professional readership and news magazines illustrate this concern, since each seems to reflect an increasing then decreasing pattern, one better described by a quadratic function of time.

Thirdly, and closely related to the preceding observation, the end point of the analysis, 1986 , is an unfortunate one in that many of the trends currently discussed in published work may have intensified in the second half of the 1980 s and the early 1990s. From our own casual empiricism we suspect that this is indeed the case for news magazines, for example. The 1986 cut off point was dictated by data availability at the time of data collection.

All told, our findings are consistent with most of the conventional wisdom concerning cigarette companies' targeting practices, at least as they are reflected in magazine advertising. A major limitation of this study was its inability to examine alleged trends in the targeting of children and people from minority groups. Though some useful work on this subject has been described recently (DP Hackbarth et al, 119th annual meeting of the American Public Health Association, Atlanta, Georgia, 1991), ${ }^{2-418}$ additional empirical research would be helpful.

The cigarette manufacturers argue that targeting is, in effect, a passive activity, an attempt to attract smokers to their brands rather than an effort to expand the market. A growing body of evidence makes this claim increasingly implausible. ${ }^{2-461920}$ Perhaps the most compelling evidence is the source of the claim itself. It comes from the same industry that persists in questioning whether smoking causes any harm to anyone's health. It is also the industry - the creator of Old Joe Camel that insists it does not want children to smoke.

This work was supported by grant number R01-DA04091 from the National Institute on Drug Abuse. We are grateful to Laura Flinchbaugh, William Foxcroft, John Grasse, Elizabeth Lowe,

1 Ernster VL. Mixed messages for women: a social history of cigarette smoking and advertising. NY State $f$ Med cigarette smoking

2 Fischer PM, Schwartz MP, Richards JW Jr, Goldstein AO, Rejas TH. Brand logo recognition by children aged 3 to 6 years: Mickey Mouse and Old Joe the Camel. $\mathcal{I} A M A$ $1991 ; 266: 3145-8$.

3 DiFranza JR, Richards JW Jr, Paulman PM, Wolf-Gillespie N, Fletcher C, Jaffe RD, et al. RJR Nabisco's cartoon camel promotes Camel cigarettes to children. $\mathcal{J} A M A$ $1991 ; 266: 3149-53$.

4 Pierce JP, Gilpin E, Burns DM, Whalen E, Rosbrook B Shopland D, et al. Does tobacco advertising target young people to start smoking? Evidence from California. fAMA 1991;266:3154-8.

5 Davis RM. Current trends in cigarette advertising and marketing. $N$ Engl $\mathcal{F}$ Med 1987;316:725-32.

6 US Department of Health and Human Services, Public Health Service, Centers for Disease Control, Center for Chronic Disease Prevention and Health Promotion,
Office on Smoking and Health. Reducing the health Office on Smoking and Health. Reducing the health
consequences of smoking : 25 years of progress. A report of consequences of smoking : 25 years of progress. A report of
the Surgeon General. Washington, DC: Government the Surgeon General. Washington, DC: Government
Printing Office, 1989. (DHHS Publication No (CDC) 89-8411.)

7 McCord C, Freeman HP. Excess mortality in Harlem. $N$ Engl f Med 1990;322: 173-7.

8 Englander TJ. Cigarette makers shift ad strategies. US Tobacco and Candy fournal 1986 Apr 2-23:1, 46

9 Blum A. The Marlboro Grand Prix: circumvention of the television ban on tobacco advertising. $N$ Engl $\mathcal{f}$ Med 1991;324:913-7.

10 Warner KE, Goldenhar LM. The cigarette advertising broadcast ban and magazine coverage of smoking and health. F Public Health Policy 1989;10:32-42.

11 Warner KE, Goldenhar LM, McLaughlin CG. Cigarette advertising and magazine coverage of the hazards of advertising and magazine coverage of the hazards of smoking:

12 Amos A, Jacobson B, White P. Cigarette advertising and coverage of smoking and health in British women's magazines. Lancet 1991;337:93-6.

13 Kessler L. Women's magazines' coverage of smoking related health hazards. Fournalism Quarterly 1989; 66:316-23.

14 Whelan EM, Sheridan MJ, Meister KA, Mosher BA. Analysis of coverage of tobacco hazards in women's magazines. F Public Health Policy $1981 ; 2: 28-35$.

15 Jacobson B, Amos A. Smoke gets in your eyes. London: British Medical Association, 1985.

16 Public Health Service. Smoking and health: report of the Advisory Committee to the Surgeon General of the Public Advisory Committee to the Surgeon General of the Public
Health Service. Washington, DC: Government Printing Health Service. Washington, DC: Govern
Office, 1964. (PHS publication No 1103.)

17 Warner KE. Cigarette advertising and media coverage of smoking and health. N Engl f Med 1985;312:384-8.

18 Maxwell B, Jacobson M. Marketing disease to Hispanics: the selling of alcohol, tobacco, and junk foods. Washington, DC: Center for Science in the Public Interest, 1989.

19 Tye JB, Warner KE, Glantz SA. Tobacco advertising and consumption: evidence of a causal relationship. $\mathcal{F}$ Public Health Policy 1987;8:492-508.

20 Laugeson $M$, Meads C. Tobacco advertising restrictions, price, income and tobacco consumption in OECD 
Translations Publicité ciblée pour les cigarettes dans of abstract

les magazines aux Etats-Unis, 1959-86
Kenneth E Warner, Linda M Goldenhar

Résumé

Objectif: Déterminer si les publicités pour les cigarettes publiées dans les magazines aux Etats-Unis entre 1959 et 1986 ciblent effectivement un public spécifique, et dans quelle mesure elles le font.

Contenu: Analyse des données sur les revenus publicitaires et sur le profil des lecteurs de 92 magazines classés par type de magazine (féminin, sur le sport, d'information, intellectuel) et par catégorie professionnelle des lecteurs (ouvrier, commerçant, profession libérale).

Principaux moyens d'évaluation obtenus: Part relative du revenu provenant de la publicité pour les cigarettes par catégorie (le pourcentage du revenu provenant de la publicité pour les cigarettes par catégorie par rapport à l'échantillon de 92 magazines, divisé par son pourcentage du revenu global de la publicité).

Résultats: Au cours des 28 ans étudiés, la part relative de la publicité pour les cigarettes a augmenté du façon considérable dans les magazines féminins (0.14 à 1.11), dans les magazines sur le sport (1.23 à 1.76$)$ et dans les magazines dont la majorité des lecteurs appartiennent à la classe ouvrière (1.04 à 1.78). La part relative dans les magazines intellectuels (se concentrant sur les commentaires politiques et intellectuels et les affaires scientifiques) a diminué (1.36 à 0.63). En 1986, les revenus de la publicité pour les cigarettes dans les magazines des classes ouvrières et les magazines sur le sport étaient de trois quarts supérieurs à leur part du revenu publicitaire global. Parmi toutes les catégories examinées, les magazines féminins ont enrégistré la plus forte augmentation de la part relative du revenu de la publicité pour les cigarettes, ce qui s'explique en partie par le fait qu'en début de période, la part relative de la publicité pour cigarettes dans ces magazines était la plus basse.

Conclusion: Dans l'ensemble, les résultats confirment la croyance générale sur le ciblage des produits du tabac.
Objectivos de la publicidad sobre el cigarrillo en revistas de los Estados Unidos, 1959-86

Kenneth E Warner, Linda M Goldenhar

\section{Resumen}

Objetivo: Analizar si en los Estados Unidos, entre 1959 y 1986 la publicidad de cigarrillos ha estado orientada y en qué medida hacia ciertos sectores de la población.

Diseño: Análisis de datos sobre ingresos por publicidad y tipo de lectores para 92 revistas clasificadas por tipo (femeninas, deportivas, de noticias, para intelectuales) y también por categoría ocupacional de los lectores (artesanos y comerciantes, y profesionales).

Principales resultados obtenidos: La participación relativa en los ingresos por publicidad de cigarrillos para cada categoría (el porcentaje de ingresos por publicidad de cigarrillos correspondiente a cada categoría de la muestra de 92 revistas, dividido entre su porcentaje del total de ingresos por publicidad).

Resultados: A lo largo de 28 años estudiados la participación relativa en la publicidad de cigarrillos aumentó significativamente en las revistas femeninas $(0,14$ a 1,11$)$, revistas de deportes $(1,23$ a 1,76$)$, y revistas cuyos lectores son principalmente trabajadores manuales $(1,04$ a 1,78$)$. La participación relativa de las revistas para intelectuales (las que se especializan en comentarios políticos $\mathrm{e}$ intelectuales $\mathrm{y}$ en asuntos científicos) bajó de 1,36 a 0,63 . Hacia 1986 , las revistas para trabajadores manuales y las deportivas tenian una participación en la publicidad sobre cigarrillos superior en $75 \%$ a su participación en los ingresos por publicidad en general. A lo largo del período en estudio, la participación relativa en los ingresos por publicidad de cigarrillos aumentó más rápidamente para las revistas femeninas que para cualquier otra de las categorías estudiadas, lo que refleja en parte que las revistas femeninas tenian la participación relativa más baja en la publicidad sobre cigarrillos al comienzo del período.

Conclusión: En general nuestros hallazgos son consistentes con las convicciones habituales acerca de la orientación de la publicidad sobre cigarrillos.

\section{美国杂志中卷烟广告的对象（1959～1986） \\ 肯尼斯・华纳 林达・哥登哈尔}

目标: 调查 1959 年至 1986 年期间内, 美国杂志中的卷烟广告是否有针对特定的对象, 以及 卷烟广告对特定对象的针对程度。

设计：将 92 种杂志按杂志的种类（妇女、体育、新间和学术）和读者的职业（工艺、贸易和 学术) 进行分类, 分析各类杂志的广告收入及各类杂志读者的分布情况.

主夏指标：每类杂志卷烟广告收入的相对比（在抽取的 92 种杂志中，每类杂志烟草广告收入 的石分比除以它在总广告收入中所占的有分比).

络果: 在所调查的 28 年中, 妇女类杂志、体育类杂志和以蓝领工人为主要读者的杂志中卷烟 广告的收入显著提高, 它们的相对比分别为 $(0.14 \sim 1.11),(1.23 \sim 1.76)$ 和 $(1.04 \sim 1.78)$. 学术性杂志 (以政治、科学和文化为主要内容) 中的漛烟广告收入则下降 $(1.36 \sim 0.63)$. 到 1986 年，以蓝领工人为主要读者的杂志和体育类杂志中的烟草广告收入占总广告收入的 $75 \%$ 以上. 在这段时间里, 如女类杂志中卷烟广告收入的相对比增长樶快, 这也部分地反映了早 期昍女杂志中卷烟广告收入是最低的.

结论：总之，我们的研究结果与公众对烟草广告对象的普逶认识是一致的. 